\title{
Epidemiological analysis of accidents with biological material in an eye hospital
}

\author{
Análise epidemiológica dos acidentes com \\ material biológicos em um hospital oftalmológico
}

Eduardo Nery Rossi Camilo1, Tiago Eugênio Faria e Arantes², Sylvia Lemos Hinrichsen³

\begin{abstract}
Objective: Toanalyzetheincidenceandcharacteristicsofaccidentswithbiological material in anophthalmologyhospital inthe Northeast ofBrazil. Methods: Retrospectivedescriptivestudyon ducted through a surveyof biological material accidents notifiedby Comunicação de Acidentes de Trabalho (CAT) during 2010-2013. Results: 34 accidents were reported, 26 (76.5\%) workers were femalesand 8 $(23.5 \%)$ were males. The mean age was $30.0 \pm 5.9$ years. Forty-eight (82.3\%) accidentsoccurred in thesurgicalroomofthe hospital, 15 (44.1\%) werewithauxiliary / practical nurses, 8 (23.5\%) withsurgicaltechnologists, 5 (14.7\%) with training physicians, 4 (11.8\%) withtrainedphysiciansand 2 (5.9\%) withcleaning staff. Accidentswerewith percutaneus in 30 (88.2\%) cases, andcontactwith mucosa in $4(11.7 \%)$. In $28(82.4 \%)$ cases theaccidentwas in theupperlimb, $4(11.8 \%)$ in the face, and $2(5.8 \%)$ in the lowerlimbs. The accidentoccurredduringsurgery in $12(35.3 \%)$ and 10 (29.4\%) duringmanipulationofthe material aftersurgery. The injuries occurred with employees who had an average of two years of experience and after 5.5 hours worked.Conclusion:Occupational accidents with biological material in an ophthalmology hospital were more frequent with auxiliary/practical nurses, during surgery and in the manipulation of instruments after surgery. This study demonstrated the importance of identifying risks of occupational accidents among health professionals in ophthalmology.
\end{abstract}

Keywords: Wounds, stab; Accidents, occupational; Biohazard release; Occupational health

\section{RESUMO}

Objetivo: Analisar a ocorrência e as características dos acidentes com material biológico em um hospital oftalmológico no nordeste, Brasil. Métodos: Estudo transversal com análise retrospectiva dos dados dos pacientes, realizada através de um levantamento dos acidentes com material biológico notificados através da Comunicação de Acidentes de Trabalho (CAT) durante o período de 2010 a 2013. Resultados: Foram notificados 34 acidentes, sendo 26 (76,5\%) em trabalhadores do gênero feminino e 8 (23,5\%) masculino. A média de idade foi $30,0 \pm 5,9$ anos. $48(82,3 \%)$ acidentes aconteceram no bloco cirúrgico da sede do hospital, 15 (44,1\%) foram com auxiliares/técnicos de enfermagem, 8 (23,5\%) com instrumentadores, 5 (14,7\%) com médicos em treinamento, 4 (11,8\%) com médicos formados e $2(5,9 \%)$ com equipe dos profissionais de limpeza. Os acidentes foram do tipo percutâneo em $30(88,2 \%)$ casos e por contato com mucosa em $4(11,7 \%)$. Em $28(82,4 \%)$ casos o acidente foi no membro superior, $4(11,8 \%)$ na face e $2(5,9 \%)$ em membros inferiores. O acidente ocorreu durante o ato cirúrgico em $12(35,3 \%)$ e $10(29,4 \%)$ durante a manipulação do material após o procedimento cirúrgico. Os acidentes aconteceram com funcionários que possuíam média de dois anos de experiência e após 5,5 horas trabalhadas.Conclusão:Os acidentes com material biológico em um hospital oftalmológico foram mais frequentes em auxiliares/técnicos de enfermagem, durante o ato cirúrgico e manipulação do instrumental após cirurgia. Este trabalho, portanto, demonstrou a importância de identificar riscos de acidentes laborais entre profissionais de saúde na área de oftalmologia.

Descritores:Ferimentos perfurantes; Acidentes de trabalho; Vazamento de risco biológico; Saúde do trabalhador

\footnotetext{
1 Fundação Banco de Olhos de Goiás, Goiânia, GO, Brazil.

2 Fundação Altino Ventura, Recife, PE, Brazil.

${ }^{3}$ Universidade Federal de Pernambuco, Universidade de Pernambuco (UPE), Recife, PE, Brazil.
}

Producing institution: Altino Ventura Foundation - Recife, PE, Brazil.

The authors declare no conflicts of interest

Received for publication 19/02/2015 - Accepted for publication 28/04/2015

Rev Bras Oftalmol. 2015; 74 (5): 284-7 


\section{INTRODUCTION}

$\mathbf{O}$ ccupational exposure to biological material is understood as the possibility of contact with blood and organic fluids in the workplace and ways of exposure include percutaneous inoculation by needles or sharp objects, as well as by direct contact with skin and/or mucous membranes. ${ }^{1.4}$

Accidental occupational exposure among health care workers is frequent due to the high number of manipulations, and pose harm to the health of workers and the institutions. ${ }^{1,2,5,6}$ Other professional members of multidisciplinary teams not directly involved with the care of patients or their body fluids may also have biological accidents, such as the employees of the cleaning staff, laundry, maintenance and garbage collection. ${ }^{2-5,7,8}$

In Brazil, concerns about the preventive measures and clinical and laboratory follow-up regarding the health professionals exposed to the risk of accidents began in the 80 s. ${ }^{5}$ Since then, there have been several pre- and post-exposure preventive barriers indicated to avoid the risk of exposure to bloodborne pathogens among health professionals, not only by the human immunodeficiency virus (HIV), but also by hepatitis $\mathrm{B}$ and $\mathrm{C}$ at the workplace. ${ }^{3-5,7,9,10} \mathrm{It}$ is known that when this type of accident occurs it should be treated as a medical emergency, since, in order to achieve greater efficiency, the procedures need to be initiated immediately after its occurrence. ${ }^{2}$

Among the various types of accidents, the cut and puncture ones are not only more frequent but also more serious, as they allow the development of life-threatening diseases to woorkers. ${ }^{11-15}$ They are responsible for $80-90 \%$ of transmission of infectious diseases among health professionals. ${ }^{1}$ The risk of transmitting infection via a contaminated needle is ine in three for Hepatitis $\mathrm{B}^{9}$, one in thirty for Hepatitis $\mathrm{C}$ and one in three hundred for HIV. ${ }^{1,2,5}$

Nowadays, the regulation of notification of these diseases must be made in a proper, standardized form by the Ministry of Health, the Brazilian Information System on Notifiable Diseases (SINAN-NET), and in specific sentinel networks, like the Worker's Health Reference Center (CEREST), so that the prevention and control policies can be executed. ${ }^{3,5,7}$

Ophthalmology involves the manipulation of cut and puncture materials both in the ambulatory and during surgical procedures, differing from other surgical modalities for using microsurgical instruments of small size often requiring manipulation with magnifying glasses and/or microscopes. For these peculiarities it is necessary to trace the profile of workers who have had accidents with biological material in eye care services so that preventive measures and improvement plans are implemented according to the specific needs and potential accident risks during the work activities. Thus, the aim of this study was to examine the occurrence and the characteristics of accidents with biological material recorded in an eye hospital in Recife, northeastern Brazil.

\section{Methods}

A retrospective and descriptive study with quantitative and qualitative approaches aimed at characterizing the occupational accidents involving biological material occurred and notified by the process of Work Accident Notification (CAT) in the period from 2010 to 2013 in Altino Ventura Foundation, Recife - PE.

All notification forms for biological material were included during the study period, being excluded the notification forms filled incompletely.

The variables analyzed included age, sex, time of employment, job category, ophthalmic subspecialty, type and topography of exposure occurred, hours worked, accident situation and sector/unit of the hospital.

The study was approved by the Research Ethics Committee of the Altino Ventura Foundation (Process: CAAE: 19376013.0.0000.5532).

The results of the categorical variables were expressed by their absolute and relative frequencies, whereas the quantitative variables were expressed by their means and standard deviations.

\section{Results}

Were recorded 34 accidents with biological materials during the study period, being 26 (76.5\%) women and $8(23.5 \%)$ men. The sample mean age was $30.0 \pm 5.9$ years. Twenty-eight $(82.3 \%)$ happened in the surgical ward of the hospital headquarters, $2(5.9 \%)$ accidents happened in the mobile surgical unit, $1(2.9 \%)$ case happened in the emergency department, and $3(8.8 \%)$ were in ambulatories. During the study period 96,720 ophthalmologic surgeries were performed in the surgical headquarter building and mobile surgical unit of the institution. Therefore, there were 3.1 accidents per 10,000 surgeries.

The accidents happened to $15(44.1 \%)$ nursing assistants / technicians, $8(23.5 \%)$ scrub nurses, $5(14.7 \%)$ ophthalmologists in training, $4(11.8 \%)$ trained ophthalmologists, and $2(5.9 \%)$ employees of the cleaning staff (Table 1). There were no reports of accidents involving anesthesiologists. Regarding the day of the week, on Monday, Tuesday, Wednesday and Friday there were each six $(17.6 \%)$ accidents, whereas on Thursday there were 7 $(20.6 \%)$ and on Saturday there were $4(11.7 \%)$.

Among the accidents, 30 (88.2\%) were percutaneous, 4 $(11.7 \%)$ by contact with the mucous membranes, 34 (100\%) by contact with blood. In $21(61.7 \%)$ cases the accident was in the finger, in $7(20.6 \%)$ in other upper limb area, $4(11.8 \%)$ in the face and $2(5.8 \%)$ in the lower limbs, 12 (35.3\%) happened during surgery, $10(29.4 \%)$ during instrument handling after surgery

\section{Table 1}

\section{Biological Accident according to the occupation and year of occurrence}

\begin{tabular}{lccccc}
\hline Occupation / Year & 2010(n) & 2011(n) & 2012(n) & 2013(n) & Total(n) \\
\hline $\begin{array}{l}\text { Trained doctors } \\
\text { Doctors in }\end{array}$ & 0 & 1 & 3 & 0 & 4 \\
training & 2 & 1 & 2 & 0 & 5 \\
Scrub nurses & 6 & 0 & 1 & 1 & 8 \\
Nurses assitants & & & & & \\
/ technicians & 2 & 4 & 7 & 2 & 15 \\
Cleaning staff & 0 & 0 & 2 & 0 & 2 \\
\hline Total & $\mathbf{1 0}$ & $\mathbf{6}$ & $\mathbf{1 5}$ & $\mathbf{3}$ & $\mathbf{3 4}$ \\
\hline
\end{tabular}


Table 2

Biological accident according to occupation and occurrence situation

\begin{tabular}{|c|c|c|c|c|c|c|}
\hline Occupation & $\begin{array}{c}\text { Needle } \\
\text { recapping (n) }\end{array}$ & $\begin{array}{l}\text { Peripheral venous } \\
\text { pounch (n) }\end{array}$ & $\begin{array}{c}\text { Postsurgical } \\
\text { material handling (n) }\end{array}$ & $\begin{array}{l}\text { Surgical } \\
\text { act }(\mathbf{n})\end{array}$ & $\begin{array}{l}\text { Material on } \\
\text { the floor (n) }\end{array}$ & $\begin{array}{c}\text { Garbage } \\
\text { cleaning (n) }\end{array}$ \\
\hline Trained doctors & 0 & 0 & 0 & 4 & 0 & 0 \\
\hline Scrub nurses & 0 & 1 & 3 & 4 & 0 & 0 \\
\hline Cleaningstaff & 0 & 0 & 0 & 0 & 0 & 2 \\
\hline Total & 2 & 7 & 10 & 12 & $\mathbf{1}$ & 2 \\
\hline
\end{tabular}

Table 3

Biological accident according to occupation and material involved

\begin{tabular}{lcccccc}
\hline Occupation & $\begin{array}{c}\text { Needle } \\
\text { with lumen }\end{array}$ & $\begin{array}{c}\text { Sclerotome } \\
\text { without lumen }\end{array}$ & Blade & Needle & $\begin{array}{c}\text { Contact with } \\
\text { mucous membrane }\end{array}$ & $\begin{array}{c}\text { Others instruments } \\
\text { without lumen }\end{array}$ \\
\hline Trained doctors & 0 & 0 & 1 & 3 & 0 & 0 \\
Doctors in training & 1 & 0 & 1 & 1 & 0 & 1 \\
Scrub nurses & 1 & 3 & 2 & 1 & 1 & 0 \\
Nurses assitants & 9 & 3 & 0 & 0 & 0 & 0 \\
/ technicians & 2 & 0 & $\mathbf{5}$ & $\mathbf{4}$ & $\mathbf{4}$ \\
Cleaningstaff & $\mathbf{1 3}$ & $\mathbf{6}$ & & & $\mathbf{2}$ \\
\hline Total & & & &
\end{tabular}

(Table 2), 4 (33.3\%) during cataract surgery, 3 (25.0\%) for retina, $2(16.7 \%)$ emergency evisceration, $1(8.3 \%)$ for cornea, 1 $(8.3 \%)$ for glaucoma, 1 (8.3\%) for strabismus.

The material which has caused the cut and puncture accident in 17 cases was the needle (13 with lumen and 4 without lumen), 6 with sclerotome, 5 with scalpel blade, 1 tweezer, and in 1 the material was not specified (Tables 2 and 3). Four occurences were due to direct contact between blood and the eye mucous membrane.

The employee's working hours in the company were on average $24.2 \pm 39.5$ months. The amount of hours worked until the time of the accident was $5.5 \pm 2.5$ hours.

All accidents were guided and referred to the State reference hospital for serological tests and immune advice. In 29 $(85.3 \%)$ cases a fast test for HIV was performed and the results were negative, and in $5(14.7 \%)$ cases this test was not done, because in 4 cases the source patient was unknown and in one case the patient was known to be HIV positive. After an evaluation of the reference hospital, 1 employee was treated preventively and at the end of the follow-up period there was no seroconversion.

\section{Discussion}

The accident with biological material may transmit infectious diseases among health professionals and trigger psychosocial effects, leading to changes in social, family and work relationships. $^{1}$

According to the literature described there was a higher prevalence of occupational accidents with biological material among the nursing assistants / technicians. ${ }^{2,4,5,7}$ The nursing assistants / technicians were the most vulnerable group, because besides being the group with more prevalence of accidents, they were caused by cut and puncture materials with lumen.

Accidents among trained ophthalmologists and among doctors in training had similar results. The highest incidence of accidents among women was due to the nursing assistants be almost entirely females.

The accidents happened on average with employees who had two years of experience and after 5.5 hours worked, suggesting that being an experienced professional is no guarantee to have safe working practices and prevent biological accidents, once said accidents may happen regardless of the time of working hours. ${ }^{11}$ Practices such as continued education on biosafety recommendations, the value of preventive actions and continued education programs that strengthen the perception of the risk of accidents and consequently the worker's quality of life can in practice be accident reduction factors. ${ }^{2,3,15}$

The accidents observed in this study happend more frequently in the surgical ward, being $35.4 \%$ during surgery and $29.4 \%$ during material handling to remove from the surgical field or cleaning the instruments. The high incidence of notifications 
by cut and puncture materials (needle, sclerotome and scalpel blade) showed the importance of taking special care with bevelled instruments, with the placement of sterile collector containers used for disposal of material in the surgical field. Studies in the literature show an increase in accidents when cut and puncture material collector containers are not available. ${ }^{5,8,10,11,14}$

Besides the accident prevention measures, clinical care and vaccinations of workers after the notification are also important. ${ }^{2,12,13}$ All company / health institution employees shall be guided and referred to reference services for occupational health / infection control, which will not only make tests, but also ensure clinical follow-up and preventive counseling for the people injured.

This study has the limitation of underreport occurred due to the lack of culture / habit of the employees to look for the sectors responsible for the control of occupational accidents.

\section{Conclusion}

Accidents with biological material in an eye hospital were more frequent in nursing assistants / technicians during surgery and instrumental manipulation after surgery. This study therefore demonstrated the importance of identifying risks of occupational accidents among ophthalmology professionals. It also demonstrated the need to create / deploy / implement occupational health programs focused on biosecurity measures and illnesses risk control. The accident prevention program must be aimed not only at increasing people's knowledge about the various preventive measures / legislation, but mainly at promoting habit and behavior change during their professional activities, which need to be safer.

\section{ReferenCes}

1. Marziale MH, Nishimura KY,Ferreira MM. Riscos de conta-minação ocasionados por acidentes de trabalho com material perfuro-cortante entre trabalhadores de enfermagem. Rev Latinoam Enferm. 2004;12(1):36-42.

2. Spagnuolo RS, Baldo RC,Guerrini IA. Análise epidemiológica dos acidentes com material biológico registrados no Centro de Referência em Saúde do Trabalhador - Londrina-PR. RevBras Epidemiol. 2008; 11(2):315-23.

3. Câmara PF,LiraC, Santos BJ, Vilella TA, Hinrichsen SL.Investigaçãode acidentesbiológicos entre profissionais da equipe multidisciplinar de um hospital, Revenferm UERJ. 2011;19(4):583-6.
4. Marziale MH, Galon T, Cassiolato FL, Girão FB. Implantação da Norma Regulamentadora 32 e o controle dos acidentes de trabalho. Acta PaulEnferm. 2012,25(6):859-866.

5. Silva JA, Paula VS,Almeida AJ, Villar LM. Investigação de acidentes biológicos entre profissionais de saúde.Esc Anna Nery RevEnferm. 2009;13(3):508-16.

6. Centers for Disease Control and Prevention. Workbook for designing, implementing, and evaluating a sharps injury prevention program [Internet].Department of Health and Human Services [internet] [cited 2008 Dec 6]. Available from: http://www.cdc.gov/sharpssafety/pdf/ sharpsworkbook_2008.pdf

7. Thompson B, Moro PL, Hancy K, Ortega-Sánchez IR, Santos-Preciado JI, Franco-Paredes C et al . Needlestick injuries among sanitation workers in Mexico City. Rev PanamSalud. 2010;27(6):467-468.

8. Orestes-Cardoso SM, Farias ABL, Pereira MR, Orestes-Cardoso AJ, Cunha IF. Acidentes perfurocortantes: prevalência e medidas profiláticas em alunos de odontologia. RevBrasSaúdeOcup.2009;34(119):6-14,

9. Brevidelli MM, Cianciarullo TI. Aplicação do modelo de crenças em saúde na prevenção dos acidentes com agulha. RevSaúdePública.2001;35(2):193-201.

10. Reis JM,Lamounier FA, Rampinelli CA, Soares EC, Prado RS, Pedroso ER. Training-related accidents during teacher-student-assistance activities of medical students. Rev Soc Bras Med Trop. 2004;37(5):405-8.

11. Lavoie M, Yassi A, Bryce E, Fujii R, Logronio M, Tennassee M. International collaboration to protect health workers from infectious diseases in Ecuador. Rev Panam Salud Publica. 2010; 27(5):396-402.

12. Menzies D, Joshi R, Pai M. Risk of tuberculosis infection and disease associated with work in health care settings. Int J Tuberc Lung Dis. 2007;11(6):593-605.

13. Ciorlia LA, Zanetta DM. Hepatitis B in healthcare workers: prevalence, vaccination and relation to occupational factors. Braz J InfectDis. 2005;9(5):384-9.

14. Bernard JA, Dattilo JR, Laporte DM. The incidence and reporting of sharps exposure among medical students, orthopedic residents, and faculty at one institution.J Surg Educ. 2013;70(5):660-8.

15. Vanhille DL, Maiberger PG, Peng A, Reiter ER. Sharps exposures among otolaryngology-head and neck surgery residents. Laryngoscope.2012;122(3):578-82.

\section{Corresponding author:}

Eduardo Nery Rossi Camilo

Rua da Soledade, 170, Boa Vista - Recife, PE, Brazil

ZIP Code 50070-040

Phone $\mathrm{n}^{\circ} .$. (81) 3302-4300

E-mail: eduardo_nery@hotmail.com 